\title{
Sexual segregation in a wide-ranging marine predator is a consequence of habitat selection
}

\author{
Ian R. Cleasby ${ }^{1,2, *}$, Ewan D. Wakefield ${ }^{1,7}$, Tom W. Bodey ${ }^{2}$, Rachel D. Davies ${ }^{1}$, \\ Samantha C. Patrick ${ }^{3,4}$, Jason Newton ${ }^{5}$, Stephen C. Votier ${ }^{6}$, Stuart Bearhop ${ }^{2}$, \\ Keith C. Hamer ${ }^{1}$

\begin{abstract}
${ }^{1}$ School of Biology, University of Leeds, Leeds LS2 9JT, UK
${ }^{2}$ Centre of Ecology and Conservation' University of Exeter, Cornwall Campus, Penryn TR10 9EZ, UK

${ }^{3}$ School of Natural and Social Sciences, University of Gloucestershire, Swindon Road, Cheltenham GL50 4HZ, UK

${ }^{4}$ Department of Zoology, South Parks Road, University of Oxford, Oxford OX1 3PS, UK

${ }^{5}$ NERC Life Sciences Mass Spectrometry Facility, SUERC, East Kilbride G75 0QF, UK

${ }^{6}$ Environment and Sustainability Institute, University of Exeter, Cornwall Campus, Penryn TR10 9EZ, UK

${ }^{7}$ Present address: Institute of Biodiversity, Animal Health and Comparative Medicine, University of Glasgow, Glasgow G12 8QQ, UK
\end{abstract}

ABSTRACT: Sexual segregation, common in many species, is usually attributed to intra-specific competition or habitat choice. However, few studies have simultaneously quantified sex-specific foraging behaviour and habitat use. We combined movement, diving, stable isotope and oceanographic data to test whether sexual segregation in northern gannets Morus bassanus results from sex-specific habitat use. Breeding birds foraging in a seasonally stratified shelf sea were tracked over 3 consecutive breeding seasons (2010-2012). Females made longer trips, foraged farther offshore and had lower $\delta^{13} \mathrm{C}$ values than males. Male and female foraging areas overlapped only slightly. Males foraged more in mixed coastal waters, where net primary production (NPP) was relatively high (>3 mg C m $\mathrm{m} \mathrm{d}^{-1}$ ) and sea-surface temperature (SST) was relatively low $\left(<10^{\circ} \mathrm{C}\right)$. Males also tended to use areas with higher $\operatorname{SSTs}\left(>15^{\circ} \mathrm{C}\right)$ more than females, possibly as a consequence of foraging in productive mixed waters over offshore banks. Females foraged most frequently in stratified offshore waters, of intermediate $\mathrm{SST}\left(12-15^{\circ} \mathrm{C}\right)$, but exhibited no consistent response to NPP. Sex-specific differences in diving behaviour corresponded with differences in habitat use: males made more long and deep Ushaped dives. Such dives were characteristic of inshore foraging, whereas shorter and shallower V-shaped dives occurred more often in offshore waters. Heavier birds attained greater depths during V-shaped dives, but even when controlling for body mass, females made deeper $\mathrm{V}$-shaped dives than males. Together,

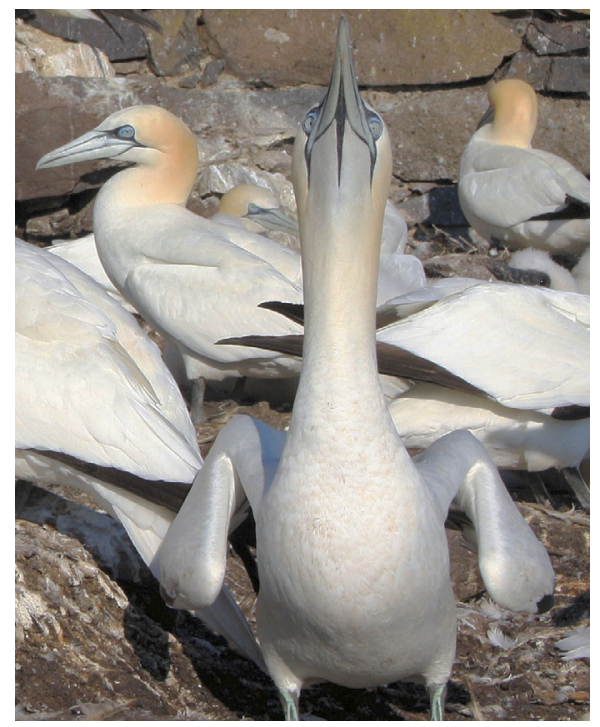

Male gannet Morus bassanus about to depart on a foraging trip.

Photo: Keith Hamer

these results indicate that sexual segregation in gannets is driven largely by habitat segregation between mixed and stratified waters, which in turn results in sex-specific foraging behaviour and dive depths.

KEY WORDS: Competition - Foraging behaviour • Oceanography · Wildlife telemetry · Northern gannet • Morus bassanus

Resale or republication not permitted without written consent of the publisher 


\section{INTRODUCTION}

Segregation of males and females occurs in a wide range of animal species and over a wide variety of spatiotemporal scales (Ruckstuhl \& Neuhaus 2005, Wearmouth \& Sims 2008, Alves et al. 2013, Levin et al. 2013). It is particularly common in marine centralplace foragers during the breeding period, when foraging ranges are restricted by the need to return repeatedly to the breeding site to care for offspring (Page et al. 2005, Weimerskirch et al. 2009). Segregation is thought to reflect niche specialisation or competitive exclusion by the dominant sex (Phillips et al. 2004) but could alternatively be a consequence of differing parental roles (Thaxter et al. 2009, Elliott et al. 2010) or differences in the nutritional requirements of males and females as proposed by Lewis et al. (2002).

In many species, between-sex differences in isotopic signatures suggest that males and females exploit different prey species or habitats (Bearhop et al. 2006, Phillips et al. 2011). However, while sexspecific habitat use has been widely documented in terrestrial species (Ruckstuhl \& Neuhaus 2005), between-sex differences in habitat use in relation to dynamic oceanographic features have rarely been quantified (but see Pinet et al. 2012). Moreover, in the marine environment, sexual segregation may occur in the vertical as well as horizontal dimension, especially in diving species (Kato et al. 2000, Lewis et al. 2002). Such vertical niche segregation may result from between-sex differences in diving capabilities mediated by morphology or physiology or as a consequence of habitat choice (Le Boeuf et al. 2000). Thus, a detailed understanding of sex-specific differences in foraging behaviour requires a combination of horizontal tracking and dive data with environmental data (Takahashi et al. 2008, Thaxter et al. 2009).

Many air-breathing diving species perform dives with 2 distinct profiles: V-shaped and U-shaped. Vshaped dives tend to be shallower and of shorter duration than U-shaped dives, which typically involve underwater propulsion (Garthe et al. 2000, Ropert-Coudert et al. 2009a). Both the dive type and depth attained may be influenced by intrinsic factors such as an individual's mass as well as extrinsic factors, including the type of prey and its depth distribution, which in turn may be influenced by the presence of other predators and the structure of the water column (Elliott et al. 2008, Machovsky Capuska et al. 2011). In addition, recent work demonstrates that dive type is determined before birds enter the water (Machovsky Capuska et al.
2013), suggesting that gannets use visual cues predive in order to optimize their foraging performance. Therefore, sex-specific differences in diving behaviour should arise as a consequence of habitat segregation as individuals adjust their foraging technique for different prey or habitats (Garthe et al. 2000).

Northern gannets Morus bassanus (henceforth gannets) are medium-range foragers, typically travelling tens to hundreds of kilometres from their colonies to obtain food for themselves and their offspring (Hamer et al. 2000, Wakefield et al. 2013). Adults exploit a wide range of prey but feed predominantly by plunge-diving for shoaling fish within the upper $30 \mathrm{~m}$ of neritic waters (Garthe et al. 2000). In addition, gannets also scavenge for discards from fishing vessels (Hamer et al. 2007, Votier et al. 2010, 2013). Gannets tracked from a large colony at Grassholm ( 40000 breeding pairs) in the Celtic Sea showed marked sexual divergence in spatial distribution and diet (Stauss et al. 2012). Males made greater use of discards from fishing vessels and foraged closer inshore than females, although it was not clear whether females fed in different areas from males as a consequence of habitat selection or whether they were displaced from fishing vessels by competition with males. In addition, time-depth recorder (TDR) data from birds breeding at Bass Rock ( 60000 pairs) in the North Sea showed that females dived to greater depths than males, suggesting that they may have been selecting different prey than males or that heavier females were able to dive deeper (Lewis et al. 2002). Gannets from both colonies forage in relatively shallow regimes (i.e. $<200 \mathrm{~m}$ ), shelf regions in which the oceanography is dominated by tidal processes (Simpson et al. 1981). In the summer months, deeper waters become thermally stratified, while coastal waters and those overlaying shallow banks remain mixed due to tidal stirring. These 2 regimes are separated by tidal mixing fronts (Simpson et al. 1981, Barnes \& Hughes 1988). Birds from Bass Rock forage in association with one such front, located $\sim 50 \mathrm{~km}$ offshore (Skov et al. 2008, Hamer et al. 2009), which we term the East Scotland tidal mixing front. The sex-specific behaviour of marine predators with respect to tidal mixing regimes has rarely been investigated. However, the foraging behaviour of many marine predators, including gannets, differs between mixed and stratified waters (Takahashi et al. 2008, Hamer et al. 2009, Camphuysen et al. 2012). Consequently, sexual niche segregation across tidal regimes may shape sex-specific differences in diving behaviour and optimal foraging strategies. 
Here, we aimed to quantify sexual differences in the foraging behaviour and habitat use of gannets foraging in the North Sea. We use a combination of horizontal and vertical tracking, stable isotope and environmental data, collected over 3 consecutive breeding seasons at Bass Rock, to address the hypotheses that during foraging: (1) sexual segregation is driven by sex-specific habitat selection; (2) habitat segregation occurs across tidal mixing regimes; and (3) sex-specific foraging behaviour arises as a consequence of habitat segregation as birds adapt their foraging behaviour to the local foraging environment.

\section{MATERIALS AND METHODS}

\section{Study site and sampling}

Fieldwork took place on Bass Rock, UK (56 $6^{\circ} 6^{\prime} \mathrm{N}$, $2^{\circ} 36^{\prime} \mathrm{W}$ ), between mid-June and mid-August in 2010 to 2012. We used a $6 \mathrm{~m}$ telescopic pole fitted with a wire crook to catch adult gannets attending young chicks at the nest. Upon capture, we fitted birds with a metal British Trust for Ornithology ring and an individually numbered plastic colour ring. We then recorded their body mass to the nearest $25 \mathrm{~g}$ using a spring balance and took $1 \mathrm{ml}$ of blood from the tarsal vein. Shortly after sampling, blood samples were separated into red blood cells (RBCs) and serum by centrifuging and stored frozen prior to stable isotope analysis and genetic sexing.

\section{Instrumentation}

A GPS logger (i-gotu 200 or 600; Mobile Action Technology) weighing $30 \mathrm{~g}$ was attached to the upper side of the 3 central tail feathers of each bird ( $\mathrm{n}=55$ birds in total; see Table S1 in the Supplement at www.int-res.com/articles/suppl/m518p001_supp.pdf) using Tesa ${ }^{\circledR}$ tape. GPS loggers were programmed to record location data at 2 min intervals. In addition, a subset of birds caught in 2011 and 2012 was fitted with a TDR (Table S1), which was taped to the underside of the central tail feathers. TDR models were either G5 (CEFAS Technology) or MSR145 (MSR Electronics), weighing $2.5 \mathrm{~g}$ and $18 \mathrm{~g}$, respectively). G5 loggers recorded pressure at $10 \mathrm{~Hz}$ when the bird was submerged (>1.5 m depth), whilst MSR145 loggers recorded pressure continuously at $1 \mathrm{~Hz}$. Total handling time was $15 \mathrm{~min}$, and after release, birds returned almost immediately to their nest and resumed normal behaviour. Birds were tracked for 4 to
7 d (Fig. S1 in the Supplement at www.int-res.com/ articles/suppl/m518p001_supp.pdf), after which time they were recaptured and the loggers retrieved. The maximum weight of loggers deployed on birds (48 $\mathrm{g}$ ) was $<2 \%$ of body mass $(3 \mathrm{~kg}$ ), and previous studies (Hamer et al. 2007, 2009) recorded that such loggers had no discernible effects on trip durations or body masses of birds. Similarly, we found that trip durations of instrumented birds in 2010 (mean \pm SD $=23.9$ $\pm 12.6 \mathrm{~h}, \mathrm{n}=211$ trips from 52 birds) were very similar to those of non-instrumented birds observed via a remote radio link using a Mobotix ${ }^{\circledR}$ surveillance camera installed in the same area of the colony (mean $=23.5 \pm 14.4 \mathrm{~h}, \mathrm{n}=636$ trips from 27 birds).

\section{Trip metrics and spatial usage}

We modelled trip duration (h), total distance travelled during each trip $(\mathrm{km})$ and time spent at the colony between trips using Bayesian linear mixed effects models (BLMM) with the R package MCMCglmm (Hadfield 2010, R Core Team 2012). All variables were log-transformed prior to analysis to ensure normality. Sex and year, and their 2-way interactions, were included as explanatory covariates, and a random intercept was specified for each bird. Minimum adequate models were selected according to their deviance information criterion scores (Lunn et al. 2013).

For each year and sex, we estimated 95 and $50 \%$ utilization distributions (UDs) using kernel analysis conducted with the $\mathrm{R}$ package adehabitatHR (Calenge 2006). The extent of within-year overlap between male and female home ranges was estimated using Bhattacharyya's affinity (BA; Bhattacharyya 1943), which ranges from 0 (no overlap) to 1 (complete overlap). Using BA as our measure of spatial overlap, we used a randomization procedure to test the null hypothesis that there was no difference in the spatial distribution of males and females each year (see the section 'Using BA and randomization to test for overlap' in the Supplement for additional information).

\section{Stable isotope analysis}

To examine sex-specific dietary niches during the breeding season, we analysed stable carbon $\left(\delta^{13} \mathrm{C}\right)$ and nitrogen isotope ratios $\left(\delta^{15} \mathrm{~N}\right) \mathrm{RBCs}$. Avian erythrocytes have a lifespan of 28 to $45 \mathrm{~d}$ (Rodnan et al. 1957) and hence represent assimilated prey over the 
previous 4 to $6 \mathrm{wk}$. In general, $\delta^{15} \mathrm{~N}$ increases by 3 to $5 \%$ with each trophic level, whereas $\delta^{13} \mathrm{C}$ typically reflects differences between water masses. Isotope analysis was conducted at the Natural Environment Research Council (NERC) Life Science Mass Spectrometry Facility, East Kilbride, UK. We modelled $\delta^{15} \mathrm{~N}$ and $\delta^{13} \mathrm{C}$ as response variables in a Bayesian multivariate analysis including year and sex as well as their 2 -way interaction as predictors; bird identity was included as a random intercept (further details in the 'Stable isotope analysis' section of the Supplement).

\section{Habitat selection}

\section{Environmental covariates}

The distribution of forage fish in the North Sea cannot currently be measured simultaneously over all scales at which we tracked gannets in this study (seconds to weeks and metres to $100 \mathrm{~s}$ of $\mathrm{km}$ ). However, foraging seabirds show marked associations with particular habitats that concentrate prey in relatively large or predictable aggregations (Wakefield et al. 2009, 2014). Previous studies have shown that northern gannets associate with shelf sea fronts and areas of high primary production (Skov et al. 2008, Votier et al. 2010). We therefore described gannet habitat using sea surface temperature (SST, ${ }^{\circ} \mathrm{C}$, Fig. $1 \mathrm{a}$, and see Fig. S2 in the Supplement) and net primary production (NPP, mg C m${ }^{-2} \mathrm{~d}^{-1}$. Figs. 1b \& S2). Monthly NPP data were estimated on a $1 \mathrm{~km}^{2}$ grid using data from the Aqua-MODIS sensor. Monthly mean SST data were supplied on a $4 \mathrm{~km}^{2}$ grid from the AVHRR sensor. All environmental data were supplied by the Natural Environment Research Council Earth Observation Data Acquisition and Analysis Service, Plymouth, UK.

\section{Habitat selection functions}

We used habitat selection functions (HSFs) to test whether males and females differed in their habitat usage. HSFs compare habitat usage to availability using a logistic-regression based approach with a case-control design (Aarts et al. 2008). The case-control design generates a binomial response $\left(\hat{u}_{i}\right)$ which takes the value 1 for the $i^{\text {th }}$ data point if it belongs to the tracking dataset or 0 if belongs to the control dataset. Tracking locations $\left(\hat{u}_{i}=1\right)$ were generated by selecting animal locations that were associated with putative foraging behaviour defined on the basis of movement indices such as speed, acceleration and track tortuosity (see Wakefield et al. 2013 for further details). The control dataset comprised 5 pseudo-
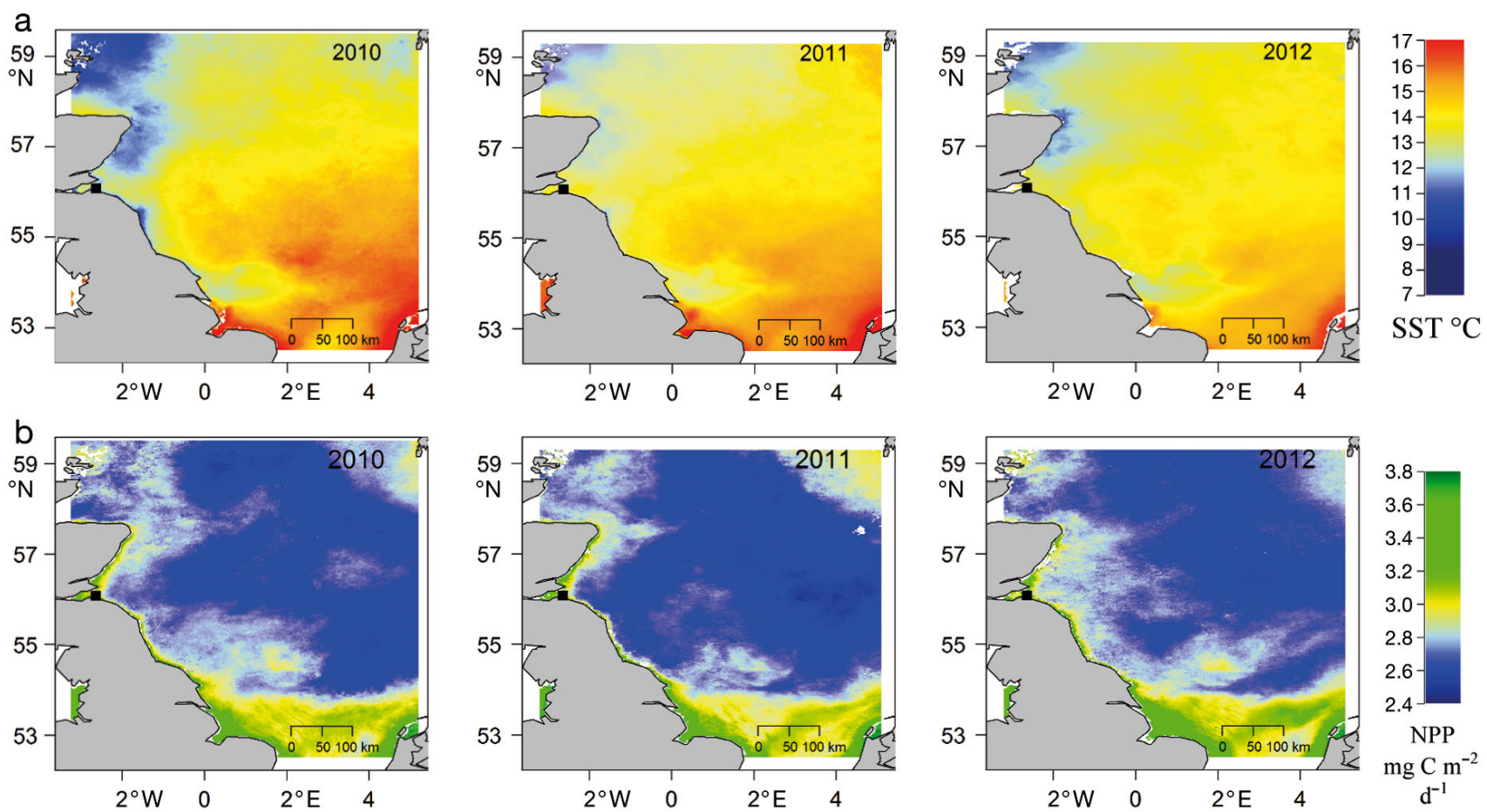

Fig. 1. Plots of the average (a) sea surface temperature (SST) and (b) net primary production (NPP) recorded during the breeding season in the foraging range of northern gannets Morus bassanus from Bass Rock, Scotland, UK (匹) for each study year 
absence locations $\left(\hat{u}_{i}=0\right)$ for each observed foraging location. Pseudo-absences were assigned to the same month as the foraging location with which they were paired and were generated randomly within the boundaries of the population's $95 \%$ UD (i.e. the UD for both sexes combined, calculated separately for each year) using a uniform spatial Poisson process.

Foraging HSFs were modelled using a binomial generalized additive mixed model (GAMM) in the mgcv R package (Wood 2006). To facilitate biological interpretation and to keep computer running time within reasonable limits ( $\sim 2 \mathrm{~h}$ to fit each model), we fitted separate models for each study year. Environmental covariates were fitted either as parametric variables, a single smoother for both sexes or as separate smoothers for each sex. The inclusion of smoothers allows for the possibility of non-linear responses to environmental covariates, and fitting separate smoothers for each sex allowed the response of males and females to differ. A random intercept was specified for each bird. In order to account for residual spatial auto-correlation, we also included a thin-plate regression spline based upon the spatial coordinates of each data point (further details in the 'GAMM analysis' section of the Supplement).

\section{Diving behaviour}

Using the TDR data, we categorised dives as either V-shaped (bottom time $\leq 2.7 \mathrm{~s}$ ) or U-shaped (bottom time $>2.7 \mathrm{~s}$; Garthe et al. 2000; see Fig. S3 and the 'TDR dive data' section of the Supplement for details). Dive locations were estimated by combining TDR and GPS data. We used a binomial GAMM to model the probability of dives being U- or V-shaped and a Gaussian GAMM to model maximum depth attained during either V- or U-shaped dives. The maximum depth of U-shaped dives was log-transformed to increase normality (no transformation was required for $\mathrm{V}$-shaped dive depth). In each model, we considered sex, body mass and the interaction between them as explanatory variables. In addition, each model included a smoother for time of day to explain diurnal variation in behaviour and a spatial smoother to account for spatial auto-correlation. Random intercepts were specified for year and for trip identity nested within bird identity. A continuous-time correlation structure was included to account for temporal auto-correlation between dives. Throughout our analysis, minimum adequate models for all GAMMs were selected by backwards selection, using $K$-folds cross-validation (where $K=5$ equal-sized subsamples of the data; more details in the 'GAMM analysis' section of the Supplement).

\section{RESULTS}

Female gannets were $\sim 200 \mathrm{~g}$ heavier than males on

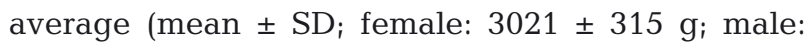
$2810 \pm 190 \mathrm{~g} ;$ Student's $t$-test $=3.71, \mathrm{df}=47, \mathrm{p} \leq$ $0.001)$.

\section{Spatial distribution of males and females}

Males made significantly shorter trips than females, both in duration $\left(\beta_{\mathrm{SEX}}=-0.14 \log (\mathrm{h}), 95 \%\right.$ Bayesian credible interval, $\mathrm{CRI}=-0.24$ to $-0.041, \mathrm{p}=$ $0.0081, \mathrm{n}=493$ trips from 55 birds; Table 1 and see Table S2 in the Supplement) and total distance travelled per trip $\left(\beta_{\mathrm{SEX}}=-0.19 \log (\mathrm{km}), 95 \% \mathrm{CRI}=-0.34\right.$ to $-0.035 \mathrm{p}=0.046$; Table 1 ). Thus, the duration of male trips was $13 \%(95 \% \mathrm{CRI}=4-21 \%)$ shorter than that of females, and the distance males travelled was $17 \%(95 \%$ CRI $=3-28 \%)$ less than that travelled by females. In general, females foraged more frequently in offshore waters to the east of the colony, whereas males foraged most frequently in coastal waters to the north-east and south-east of the colony (Figs. 2 \& S1). Consequently, the overlap between male and female 50 and $95 \%$ UDs was significantly lower than the null expectation each year, except for the $50 \%$ UD in 2011, which was marginally significant $(\mathrm{p}=0.052)$ and the $95 \%$ UD in $2012(\mathrm{p}=0.083$; Table 2).

Table 1. Summary of foraging trip and dive metrics for northern gannets Morus bassanus at Bass Rock, Scotland, UK; $\mathrm{n}$ : number of trips or dives

\begin{tabular}{|llccc|}
\hline Variable & Sex & Mean (SD) & Range & $\mathrm{n}$ \\
& & & & \\
\hline Trip duration (h) & Male & $21.40(12.02)$ & $0.91-69.76$ & 493 \\
& Female & $24.14(12.77)$ & $3.71-95.11$ & \\
Trip length (km) & Male & $454.63(277.79)$ & $27.32-1265.72$ & 493 \\
& Female & $512.56(262.74)$ & $69.64-1461.62$ & \\
Time at colony & Male & $10.31(8.53)$ & $1.07-24.76$ & 379 \\
between trips (h) & Female & $10.11(8.59)$ & $1.07-48.51$ & \\
Maximum V-dive & Male & $4.40(1.92)$ & $1.52-11.03$ & 4274 \\
depth (m) & Female & $6.69(2.01)$ & $1.52-9.25$ & \\
Maximum U-dive & Male & $7.23(4.06)$ & $1.64-27.75$ & 2036 \\
depth (m) & Female & $7.59(3.78)$ & $1.70-25.96$ & \\
\hline
\end{tabular}



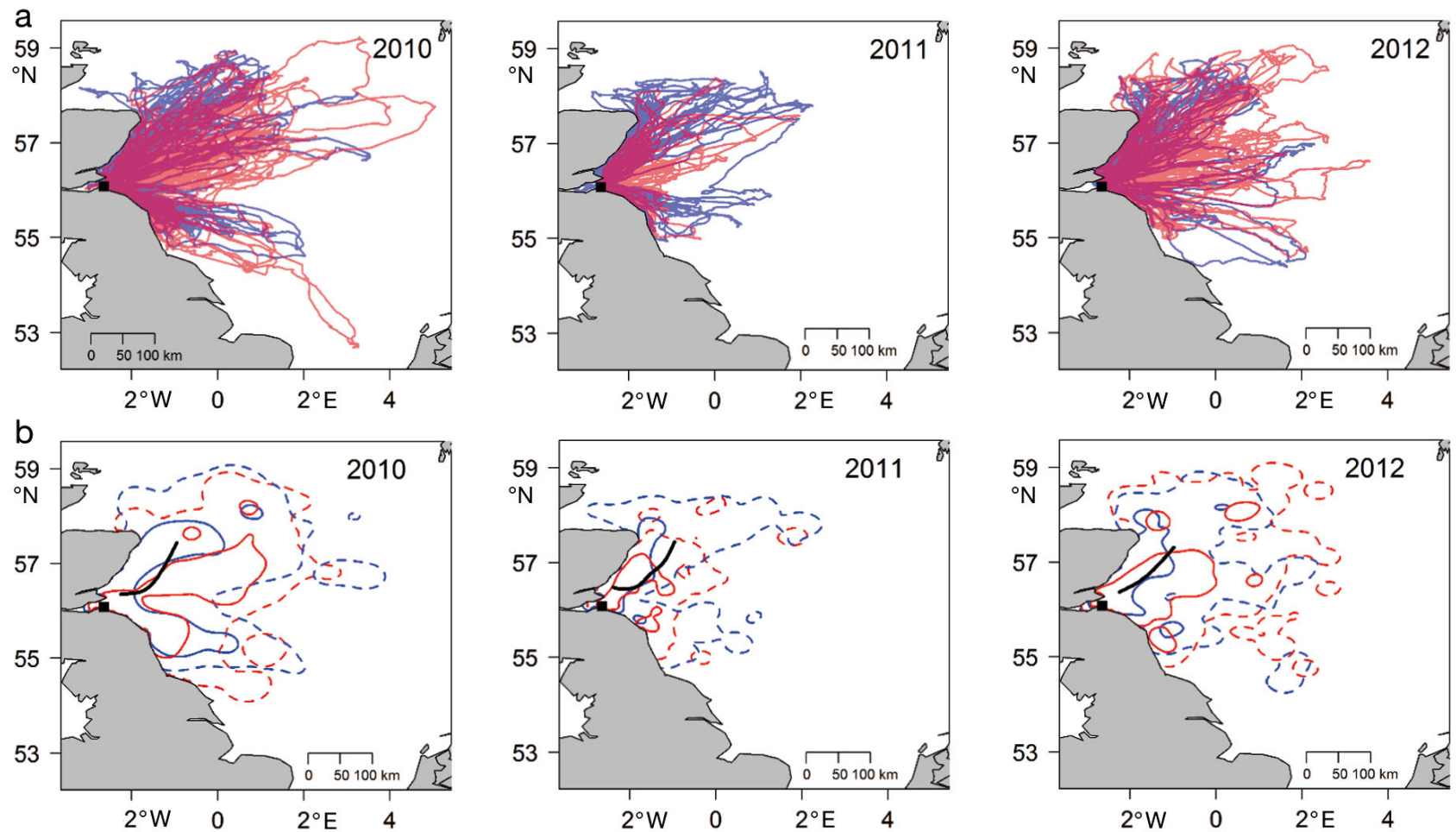

Fig. 2. Foraging ranges of male (blue) and female (red) northern gannets Morus bassanus during the breeding season in each study year. (a) Raw location data; (b) kernel density based utilization distributions at 95\% (dotted lines) and 50\% (solid lines). Bass Rock, Scotland, is shown as a square (घ), and the approximate position of the tidal mixing front each year is shown as a solid black line in (b)

\section{HSFs}

In each year, the best fitting model contained a sexspecific smoother for SST and NPP (Tables S3 \& S4). Both random intercepts for bird identity and spatial smoothers (Fig. S4) were retained in the final models. Females foraged mainly over waters with a temperature between 10 and $15^{\circ} \mathrm{C}$. In contrast, males foraged relatively little over such waters, tending to forage in significantly cooler $\left(8-12^{\circ} \mathrm{C}\right)$ or warmer waters

Table 2. Estimated overlap (Bhattacharyya's affinity, BA) in utilization distributions (UD) between male and female northern gannets Morus bassanus from Bass Rock, Scotland; $\mathrm{p}$ : the proportion of randomized overlaps that were smaller than the observed overlap

\begin{tabular}{|lccc|}
\hline UD $(\%)$ & Year & BA & $p$ \\
\hline 50 & 2010 & 0.22 & 0.046 \\
& 2011 & 0.25 & 0.052 \\
& 2012 & 0.22 & 0.022 \\
95 & 2010 & 0.75 & 0.011 \\
& 2011 & 0.65 & 0.027 \\
& 2012 & 0.76 & 0.083 \\
\hline
\end{tabular}

$\left(>15^{\circ} \mathrm{C}\right.$, Fig. 3a). In addition, males made greater use than females of areas with high NPP $\left(>3 \mathrm{mg} \mathrm{C} \mathrm{m}^{-2} \mathrm{~d}^{-1}\right.$; Fig. 3b).

\section{Stable isotope ratios}

Male RBCs had significantly higher $\delta^{13} \mathrm{C}$ values than those of females in each study year and significantly higher $\delta^{15} \mathrm{~N}$ values than females in 2010 and 2011, but not during 2012 (Fig. 4, Table 3).

\section{Diving behaviour}

V-shaped dives were more frequent than U-shaped dives across both sexes (total number of V-dives = 4784 ; total number of U-dives $=2151$ ), but males were more likely than females to make U-shaped dives (males: $38 \%$ of 3904 dives classed as U-shaped; females: $22 \%$ of 3031 dives classed as U-shaped; $\beta_{\mathrm{SEX}}=0.92,95 \%$ confidence interval, $\mathrm{CI}=0.35-1.48$, $\mathrm{p}=0.0012, \mathrm{n}=6310$ dives from 23 birds; Table S5). Body mass did not affect the probability of a dive 

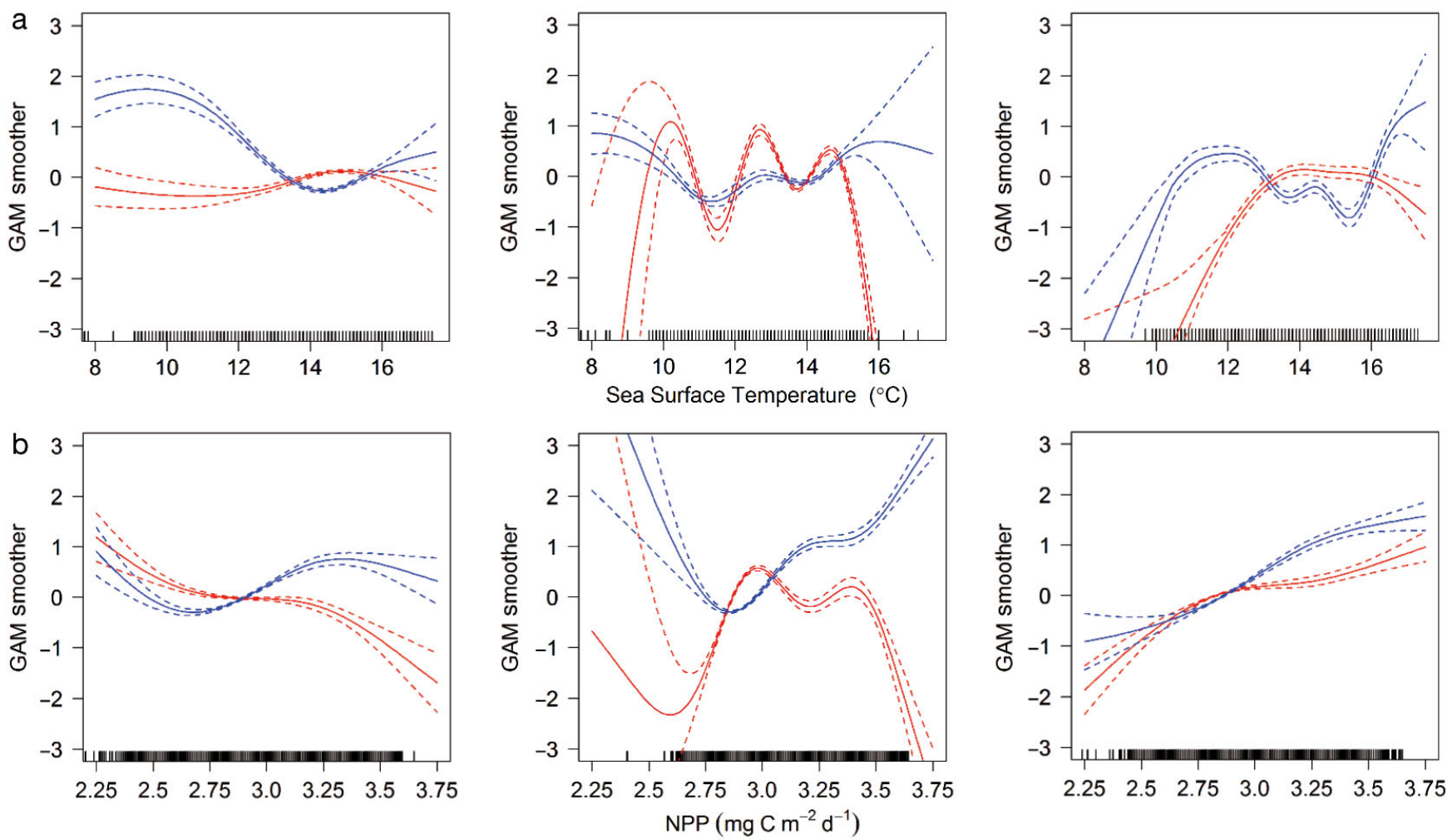

Fig. 3. Habitat selection functions for (a) sea surface temperature (SST) and (b) net primary production (NPP). Plots show the predicted curve from the model (solid line) and 95\% confidence intervals (dashed lines) for male (blue) and female (red) northern gannets Morus bassanus. GAM: generalized additive model

being U-shaped or V-shaped ( $\beta_{\text {MASS }}=-0.024,95 \%$ CI $=-0.29$ to $+0.25, \mathrm{p}=0.90$; Tables S5 \& S6). Plots of dive locations and the spatial smoother from the dive

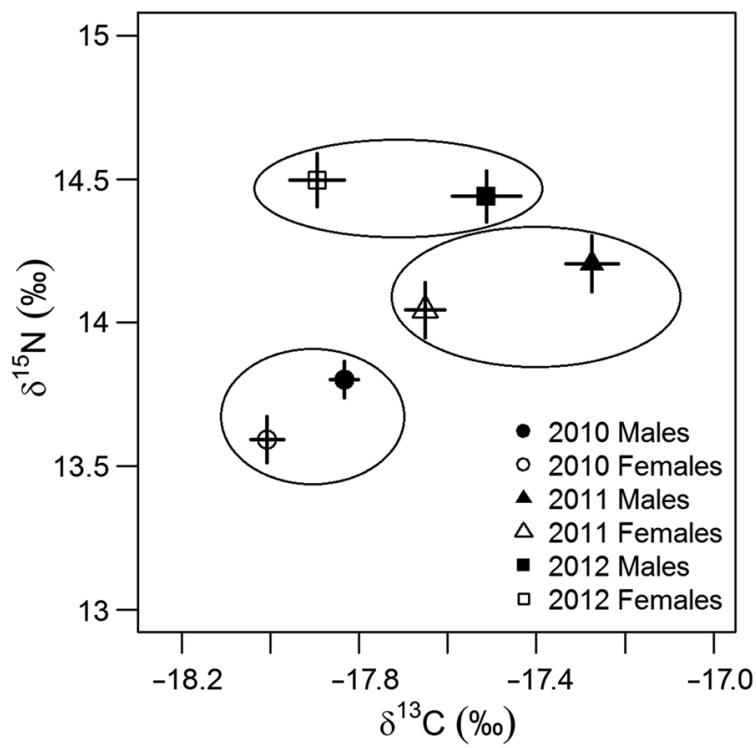

Fig. 4. Mean $\pm \mathrm{SE} \delta^{13} \mathrm{C}$ and $\delta^{15} \mathrm{~N}$ values in red blood cells of breeding northern gannets Morus bassanus from Bass Rock, Scotland. Ellipses show values from the same year type model indicate that in both sexes, U-shaped dives were more likely to occur close to the colony and inshore of the East Scotland tidal mixing front (Fig. 5). Dives at dawn or dusk were more likely to be V-shaped than U-shaped (Fig. S5).

The maximum depth achieved during V-shaped dives was positively associated with body mass $\left(\beta_{\mathrm{MASS}}=0.52,95 \% \mathrm{CI}=0.31-0.91, \mathrm{p}=0.019\right)$. In addition, after controlling for body mass, the maximum depth attained during $\mathrm{V}$-shaped dives was greater in females than males (Table $1 ; \beta_{\mathrm{SEX}}=-0.81,95 \% \mathrm{CI}=$ -1.55 to $+0.11, \mathrm{p}=0.021, \mathrm{n}=4272$ dives, 23 birds; Tables S7 \& S8). In both sexes, the deepest V-shaped dives tended to occur in offshore waters (Fig. 6a), and V-shaped dives were shallowest at dawn and dusk (Fig. S6a). There was little difference in the maximum depth reached by males and females during U-shaped dives $\left(\beta_{\mathrm{SEX}}=0.11,95 \% \mathrm{CI}=-0.086\right.$ to $+0.31, \mathrm{p}=0.28, \mathrm{n}=2036$ dives, 23 birds; Tables 1, S9 $\&$ S10), nor was there a significant association between maximum depth and body mass $\left(\beta_{\mathrm{MASS}}=\right.$ $0.073,95 \% \mathrm{CI}=-0.026$ to $+0.17, \mathrm{p}=0.16$ ). The maximum depth of U-shaped dives generally increased closer to the colony (Fig. 6b), and U-shaped dives were also shallower at dawn and dusk (Fig. S6b). 
Table 3. Bayesian multivariate mixed effects model of $\delta^{15} \mathrm{~N}$ and $\delta^{13} \mathrm{C}$ in northern gannets Morus bassanus from Bass Rock, Scotland ( $\mathrm{n}=138$ observations of 66 birds)

\begin{tabular}{|c|c|c|c|c|c|c|c|c|}
\hline \multirow[t]{2}{*}{ Variable } & \multicolumn{4}{|c|}{$\delta^{15} \mathrm{~N}$} & \multicolumn{4}{|c|}{$-\delta^{13} \mathrm{C}$} \\
\hline & $\beta$ & Lower $95 \%$ CI & Upper $95 \%$ CI & $\mathrm{p}$ & $\beta$ & Lower $95 \%$ CI & Upper $95 \%$ CI & $\mathrm{p}$ \\
\hline Intercept & 13.55 & 13.40 & 13.67 & $<0.001$ & -18.04 & -18.11 & -17.95 & $<0.001$ \\
\hline Sex & 0.27 & 0.09 & 0.46 & 0.007 & 0.19 & 0.08 & 0.31 & 0.001 \\
\hline Year 2011 & 0.48 & 0.29 & 0.68 & $<0.001$ & 0.38 & 0.24 & 0.52 & $<0.001$ \\
\hline Year 2012 & 0.90 & 0.72 & 1.09 & $<0.001$ & 0.11 & -0.02 & 0.24 & 0.100 \\
\hline Sex $\times$ Year 2011 & -0.10 & -0.36 & 0.17 & 0.480 & 0.20 & 0.02 & 0.48 & 0.022 \\
\hline Sex $\times$ Year 2012 & -0.31 & -0.59 & -0.02 & 0.022 & 0.21 & 0.03 & 0.41 & 0.036 \\
\hline
\end{tabular}
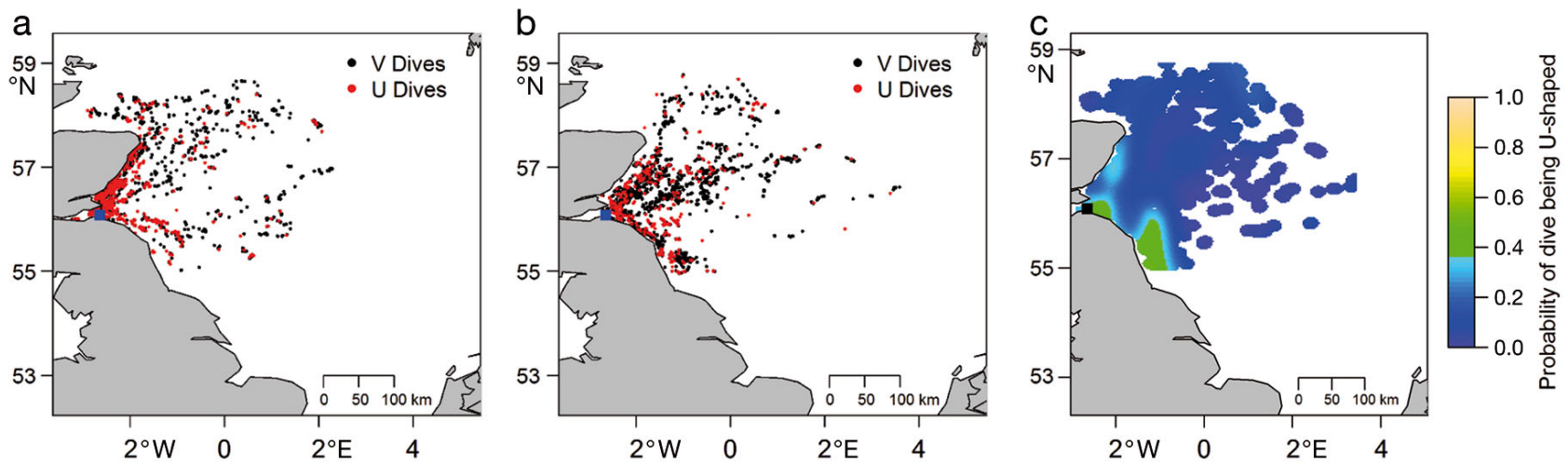

Fig. 5. Locations of U-shaped (red) and V-shaped (black) dives by (a) male and (b) female northern gannets Morus bassanus. (c) Plot of the spatial smoother from the generalized additive mixed model dive-type analysis showing the predicted probability that a dive will be classed as U-shaped. The square in all panels denotes the position of Bass Rock, Scotland

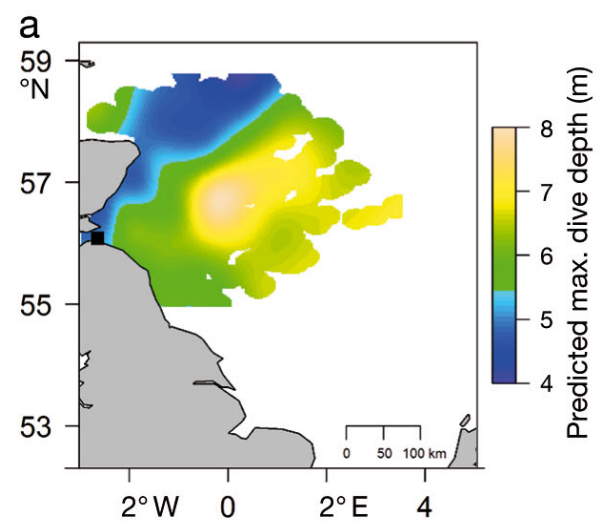

DISCUSSION

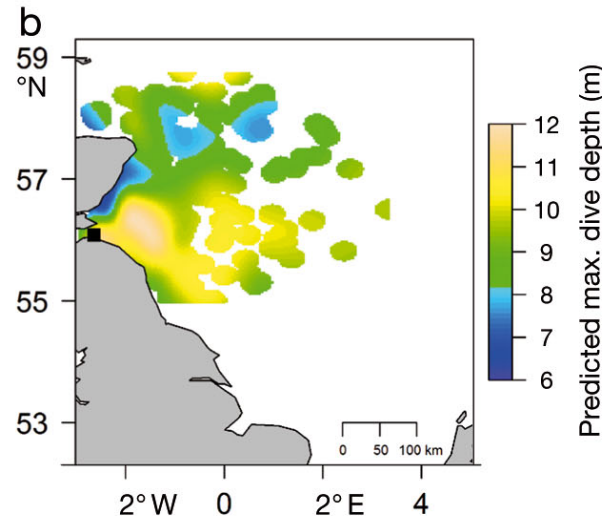

Differences in habitat usage
This study provides clear evidence of sexual segregation in northern gannets in both horizontal and vertical planes. Males and females differed in their usage of mixed and stratified waters, providing evidence for sex-specific habitat segregation across tidal mixing regimes. Moreover, our results highlight the association between sex-specific foraging behaviour and spatial and habitat segregation.
Males foraged predominantly in mixed waters to the north-east of Bass Rock inshore of the tidal mixing front, whereas females foraged predominantly in offshore stratified waters. These results are consistent with previous work showing that chick-provisioning males from Bass Rock departed on more north-easterly bearings than females (Lewis et al. 2004) and that chick-provisioning 
females from Grassholm foraged farther offshore than males in the Celtic Sea (Stauss et al. 2012). $\mathrm{RBC} \delta^{13} \mathrm{C}$ values were lower in females than in males at Bass Rock, which also indicates that females foraged farther offshore than males, because inshore habitats characteristically have higher $\delta^{13} \mathrm{C}$ values (Hobson et al. 1994). Lower blood $\delta^{13} \mathrm{C}$ values in females have also been observed at other gannet colonies (Stauss et al. 2012), suggesting that our results reflect a general feature in gannets. Males made greater use than females of areas with high NPP, as would be expected given that NPP is generally higher in mixed, coastal waters where males foraged (Fig. S2). NPP is often used as a proxy for food availability farther up the food chain (Barnes \& Hughes 1988, Wakefield et al. 2014), suggesting that males foraged in a more productive environment than females. However, potential mismatches between productivity towards the bottom of the food web and at intermediate trophic levels (pelagic fish) means that this interpretation should be treated with caution (Grémillet et al. 2008).

Male gannets from Bass Rock had higher $\delta^{15} \mathrm{~N}$ values than females in 2010 and 2011, but not in 2012 . Higher $\delta^{15} \mathrm{~N}$ in males from Grassholm may occur if males consume a higher proportion of whitefish fishery discards than females (Stauss et al. 2012). However, at Bass Rock, the between-sex differences in $\delta^{15} \mathrm{~N}$ each year were small and could have arisen from the observed habitat segregation between males and females (as a consequence of variation in isotopic baselines in the areas where individuals foraged; Woodcock et al. 2012) or from lower body condition among males (as a consequence of variation in physiological processes affecting fractionation; Lee Cruz et al. 2012) or both.

Sex-specific responses to SST were generally consistent across years, with males foraging more in cold mixed waters and females foraging in seasonally stratified offshore waters. As well as using colder waters more often than females, males also made greater use of areas with high $\operatorname{SSTs}\left(>15^{\circ} \mathrm{C}\right)$. This was a consequence of males travelling south-east to forage at the Dogger Bank, where SST was relatively high. The Dogger Bank is a productive shallow offshore bank, which is also targeted by other wideranging higher predators (de Boer 2010). Due to benthic-pelagic coupling, such features may lead to elevated prey abundance in the epipelagic waters accessible to gannets (Wakefield et al. 2012). In 2011, differences between male and female responses to SST were smaller (Figs. $1 \& 2$ ), probably because the
East Scotland tidal mixing front was located closer to shore and the extent of cold mixed waters (SST < $10^{\circ} \mathrm{C}$ ) was relatively limited (Fig. 1a). Between 2010 and 2012, there was also variation in climatic conditions in the North Atlantic as indicated by the North Atlantic Oscillation index which varied from -4.64 in 2010 to 3.17 in 2012 (https://climatedataguide.ucar. edu/climate-data/hurrell-north-atlantic-oscillationnao-index-station-based). Effects of climate on lower levels of the food web may, in turn, have influenced both the locations where gannets foraged and the prey species they targeted. Thus, our results highlight the importance of inter-annual variation in oceanic and climatic conditions in shaping the spatial and trophic ecology of marine predators (Garthe et al. 2011).

\section{Sex-specific diving behaviour}

Males and females may adopt different diving tactics as a consequence of intrinsic constraints, competition, habitat segregation or prey preferences (Le Boeuf et al. 2000, Machovsky Capuska et al. 2011). At Bass Rock, male gannets made a greater proportion of U-shaped dives than females. Moreover, U-shaped dives were more frequent in coastal habitats, whilst V-shaped dives were more frequent offshore. Therefore, the different dive types may represent tactics for foraging in different environments, with males making more U-dives as a consequence of their inshore distribution and the prey they encounter.

The higher frequency of U-dives in the vicinity of Bass Rock, and the greater depth of U-dives close to the colony, may arise due to the high density of gannets in these areas. In particular, when large aggregations of gannets form during feeding events, prey may descend to deeper depths to escape predation, forcing gannets to dive deeper (Elliott et al. 2008, Machovsky Capuska et al. 2011). However, this would not explain why U-shaped dives are also more frequent in coastal areas farther from the colony, where the density of conspecifics is lower (Camphuysen et al. 2012). Instead, diving behaviour may reflect the environment and prey encountered (Garthe et al. 2000, 2011), as observed in other marine predators which dived deeper in mixed waters than in stratified waters (Takahashi et al. 2008). In particular, the location of the deepest U-shaped dives corresponds with the location of sandeel (Ammodytes spp.) habitat within the Firth of Forth (Wanless et al. 1998), thus deeper U-shaped dives could result from birds feeding on sandeels. Alternatively, the shallower waters 
in coastal areas may prevent prey escaping to deeper depths, enhancing prey capture and making longer U-shaped dives more profitable than in deeper waters.

Females attained greater depths than males during V-shaped dives, which supports similar findings in gannets and other Sulidae (Lewis et al. 2002, Zavalaga et al. 2007, Weimerskirch et al. 2009). Gannets initially attain depth by plunge-diving from height; therefore, the greater mass of females may give them greater dive momentum and allow them to dive deeper (Kato et al. 2000). However, even when accounting for body mass in our models, females were still predicted to reach deeper depths during V-shaped dives than males. Such a difference may reflect the vertical distribution of prey that males and females target when foraging or assessing prey densities (Wilson 2003, Machovsky Capuska et al. 2011, 2013). For example, because females tend to forage more in offshore stratified waters than males, deeper V-shaped dives may be required to reach the thermocline, which influences the distribution of biomass in the water column (Mann \& Lazier 2006) and can play a role in shaping dive profiles (Takahashi et al. 2008, Ropert-Coudert et al. 2009b).

Body mass had no effect on the depth of U-shaped dives, probably because extra depth can be achieved during U-shaped dives by underwater swimming after the initial momentum phase (Ropert-Coudert et al. 2009a).

\section{Factors underlying segregation}

Sex-specific differences in foraging behaviour are usually ascribed to the influence of body size on foraging efficiency and intra-specific competition (Shaffer et al. 2001, Wearmouth \& Sims 2008, Phillips et al. 2011). Competition may play a greater role in segregating birds from the same colony than it does in between-colony segregation (Wakefield et al. 2013) because the rate at which indirect competition varies with colony distance will be equal for all individuals at the colony. Because males made shorter trips than females, it is possible that females were excluded from areas close to the colony via indirect competition and were pushed into offshore, stratified waters as a result. However, this would not explain why females did not appear to be pushed into inshore sites farther from the colony in a similar fashion. Moreover, when the tidal mixing front was less welldefined and occurred closer to the coastline in 2011, the $50 \%$ UD of females shifted inshore, suggesting that females are not excluded from this area.
Alternatively, the greater mass of females may make them more efficient at foraging in offshore environments because they can reach deeper prey. Greater mass appears to be advantageous when performing V-dives, and as the deepest V-dives occurred in stratified waters, this may give females an advantage in this environment. Nevertheless, the slight sexual size dimorphism $(\sim 5-10 \%)$ seen in gannets suggests that differences in body mass alone will not create large asymmetries in either competitive ability or foraging efficiency. Therefore, other aspects of morphology not measured here, such as wing loading and agility (Weimerskirch et al. 2006), may be important. Finally, the fact that in addition to Bass Rock, females breeding at Grassholm also foraged farther offshore than males (Stauss et al. 2012), despite differences between regions in the arrangement of mixed and stratified waters, suggests that sexual segregation is driven primarily by habitat selection.

Sex-specific niche divergence and habitat segregation can also arise from a difference between sexes in parental roles (Thaxter et al. 2009), but the roles of male and female gannets do not appear to differ during chick-rearing (Nelson 2002, Redman et al. 2002). However, males and females could forage in different areas in order to ensure that their chicks receive the optimum blend of prey species (Elliott et al. 2010). Sex-specific differences in nutritional requirements related to egg production, incubation costs or feather moult could also result in sexual segregation (Carey 1996, Lewis et al. 2002), particularly if key prey items are found in specific habitats. However, gannets lay only a single, small egg, so it seems unlikely that this would cause temporary sex differences in dietary need. It is not known whether there are sex-specific differences in moult in gannets, but such differences do occur in other seabirds (Weimerskirch 1991) and could potentially create temporary sex differences in dietary needs and/or foraging abilities (Lewis et al. 2002).

Overall, our results suggest that sexual segregation in gannets is mediated by habitat segregation across tidal mixing regimes. Males foraged more in mixed coastal waters inshore of the tidal mixing front whereas females foraged more offshore. Hence, while tidal mixing regimes have been identified as important habitat features for marine predators (Skov et al. 2008), males and females may respond differently to such features. In addition, sex-specific diving behaviour may result from males and females adapting their behaviour to suit the differing habitats in which they forage, particularly in relation to whether they are foraging in mixed or stratified waters. 
Acknowledgements. We thank Sir Hew Hamilton-Dalrymple for access to the Bass Rock and are grateful to Maggie Sheddan and the Scottish Seabird Centre for logistic support and advice. Fieldwork was carried out with approval from the British Trust for Ornithology (permits for attachment of rings and data loggers, the UK Home Office (personal and project licenses for blood sampling) and Scottish Natural Heritage. Funding was provided by the Natural Environment Research Council (Standard Grant NE/H007466/1 to K.C.H., S.B. and S.C.V.). We thank the NERC Earth Observation Data Acquisition and Analysis Service (NEODAAS) for supplying data for this study.

\section{LITERATURE CITED}

Aarts G, MacKenzie M, McConnell B, Fedak M, Matthiopoulos J (2008) Estimating space-use and habitat preference from wildlife telemetry data. Ecography 31:140-160

- Alves JA, Gunnarsson TG, Potts PM, Sutherland WJ, Gill JA (2013) Sex-biases in distribution and resource use at different spatial scales in a migratory shorebird. Ecol Evol 3: 1079-1090

Barnes RSK, Hughes RN (1988) An introduction to marine ecology. Blackwell Science, Oxford

Bearhop S, Phillips RA, McGill R, Cherel Y, Dawson DA, Croxall JP (2006) Stable isotopes indicate sex-specific and long-term individual foraging specialisation in diving seabirds. Mar Ecol Prog Ser 311:157-164

Bhattacharyya A (1943) On a measure of divergence between two statistical populations defined by their probability distributions. Bull Calcutta Math Soc 35:99-109

> Calenge C (2006) The package 'adehabitat' for the R software: a tool for the analysis of space and habitat use by animals. Ecol Model 197:516-519

Camphuysen KCJ, Shamoun-Baranes J, Bouten W, Garthe S (2012) Identifying ecologically important marine areas for seabirds using behavioural information in combination with distributional patterns. Biol Conserv 156:22-29

Carey C (1996) Female reproductive energetics. In: Carey C (ed) Avian energetics and nutritional ecology. Chapman \& Hall, New York, NY, p 324-374

$>$ De Boer MN (2010) Spring distribution and density of minke whale Balaenoptera acutorostrata along an offshore bank in the central North Sea. Mar Ecol Prog Ser 408: 265-274

Elliott KH, Woo K, Gaston AJ, Benvenuti S, Dall'Antonia L, Davoren GK (2008) Seabird foraging behaviour indicates prey type. Mar Ecol Prog Ser 354:289-303

Elliott KH, Gaston AJ, Crump D (2010) Sex-specific behavior by a monomorphic seabird represents risk partitioning. Behav Ecol 21:1024-1032

Garthe S, Benvenuti S, Monthevecchi WA (2000) Pursuitplunging by gannets (Morus bassanus) feeding on capelin (Mallotus villosus). Proc R Soc Lond B Biol Sci 267:1717-1722

Garthe S, Montevecchi WA, Davoren GK (2011) Interannual changes in prey fields trigger different foraging tactics in a large marine predator. Limnol Oceanogr 56: 802-812

Grémillet D, Lewis S, Drapeau L, van Der Linge CD and oters (2008) Spatial match-mismatch in the Benguela upwelling zone: should we expect chlorophyll and sea-surface temperature to predict marine predator distributions? J Appl Ecol 45:610-621
Hadfield JD (2010) MCMC methods for multi-response generalized linear mixed models: the MCMCglmm R package. J Stat Softw 33:1-22

Hamer KC, Phillips RA, Wanless S, Harris MP, Wood AG (2000) Foraging ranges, diets and feeding locations of gannets Morus bassanus in the North Sea: evidence from satellite telemetry. Mar Ecol Prog Ser 200:257-264

> Hamer KC, Humphreys EM, Garthe S, Hennicke J and others (2007) Annual variation in diets, feeding locations and foraging behaviour of gannets in the North Sea: flexibility, consistency and constraint. Mar Ecol Prog Ser 338: 295-305

> Hamer KC, Humphreys EM, Magalhães MC, Garthe S and others (2009) Fine-scale foraging behaviour of a mediumranging marine predator. J Anim Ecol 78:880-889

Hobson KA, Piatt JF, Pitocchelli J (1994) Using stable isotopes to determine seabird trophic relationships. J Anim Ecol 63:786-798

Kato A, Watanuki Y, Nishiumi I, Kuroki M, Shaughnessy P, Naito Y (2000) Variation in foraging and parental behavior of king cormorants. Auk 117:718-730

> Le Boeuf BJ, Crocker DE, Costa DP, Blackwell SB, Webb PM, Houser DS (2000) Foraging ecology of northern elephant seals. Ecol Monogr 70:353-382

> Lee Cruz L, McGill R, Goodman SJ, Hamer KC (2012) Stable isotope ratios of a tropical marine predator: confounding effects of nutritional status during growth. Mar Biol 159: 873-880

Levin E, Roll U, Dolev A, Yom-Tov Y, Kronfeld-Shcor N (2013) Bats of a gender flock together: sexual segregation in a sub-tropical bat. PLoS ONE 8:e54987

Lewis S, Benvenuti S, Dall'Antonia L, Griffiths RG and others (2002) Sex-specific foraging behaviour in a monomorphic seabird. Proc R Soc Lond B Biol Sci 269: 1687-1693

Lewis S, Hamer KC, Money L, Griffiths R, Wanless S, Sherratt TN (2004) Brood neglect and contingent foraging behaviour in a pelagic seabird. Behav Ecol Sociobiol 56: 81-88

Lunn D, Jackson C, Best N, Thomas A, Spiegelhalter D (2013) The BUGS book: a practical introduction to Bayesian analysis. CRC Press, London

> Machovsky Capuska GE, Vaughn RL, Würsig B, Katzir G, Raubenheimer D (2011) Dive strategies and foraging effort in the Australasian gannet Morus serrator revealed by underwater videography. Mar Ecol Prog Ser 442: 255-261

Machovsky Capuska GEM, Vaughn-Hirshorn RL, Würsig B, Raubenheimer D (2013) Can gannets (Morus serrator) select their diving profile prior to submergence? Notornis 60:255-257

Mann KH, Lazier JRN (2006) Dynamics of marine ecosystems: biological-physical interactions in the oceans. Wiley-Blackwell, Oxford

Nelson JB (2002) The Atlantic gannet, 2nd edn. Fenix Books Ltd, Norfolk

Page B, McKenzie J, Goldsworthy SD (2005) Inter-sexual differences in New Zealand fur seal diving behaviour. Mar Ecol Prog Ser 304:249-264

Phillips RA, Silk JRD, Phalan B, Catry P, Croxall JP (2004) Seasonal sexual segregation in two Thalassarche albatross species: competitive exclusion, reproductive role specialization or foraging niche divergence? Proc R Soc Lond B Biol Sci 217:1283-1291

> Phillips RA, McGill RAR, Dawson DA, Bearhop S (2011) 
Sexual segregation in distribution, diet and trophic level of seabirds: insights from stable isotope analysis. Mar Biol 158:2199-2208

Pinet P, Jaquemet S, Phillips RA, Le Corre M (2012) Sexspecific foraging strategies throughout the breeding season in a tropical, sexually monomorphic small petrel. Anim Behav 83:979-989

R Core Team (2012) R: a language and environment for statistical computing. R Foundation for Statistical Computing, Vienna. www.R-project.org/

Rodnan GP, Ebaugh FG, Fox MS, Chambers DM (1957) The life span of the red blood cell and the red blood cell volume in the chicken, pigeon and duck as estimated by the use of Na2Cr51O4 with observations on red cell turnover rate in the mammal, bird and reptile. Blood 12:355-366

Redman KK, Lewis S, Griffiths R, Wanless S, Hamer KC (2002) Sexing northern gannets from DNA, morphology and behavior. Waterbirds 25:230-234

Ropert-Coudert Y, Daunt F, Kato A, Ryan PG and others (2009a) Underwater wingbeats extend depth and duration of plunge dives in northern gannets Morus bassanus. J Avian Biol 40:380-387

Ropert-Coudert Y, Kato A, Chiaradia A (2009b) Impact of small-scale environmental perturbations on local marine food resources: a case study of a predator, the little penguin. Proc R Soc Lond B Biol Sci 276:4105-4109

Ruckstuhl K, Neuhaus P (2005) Sexual segregation in vertebrates: ecology of the two sexes. Cambridge University Press, Cambridge

Shaffer SA, Weimerskirch H, Costa DP (2001) Functional significance of sexual dimorphism in wandering albatrosses Diomedea exulans. Funct Ecol 15:203-210

- Simpson JH, Crisp DJ, Hearn C (1981) The shelf-sea fronts: implications of their existence and behaviour [and discussion]. Philos Trans R Soc Lond A Math Phys Eng Sci 302:531-546

Skov H, Humphreys E, Garthe S, Geitner K and others (2008) Application of habitat suitability modelling to tracking data of marine animals as a means of analyzing their feeding habitats. Ecol Model 212:504-512

Stauss C, Bearhop S, Bodey TW, Garthe S and others (2012) Sex-specific foraging behaviour in northern gannets Morus bassanus: incidence and implications. Mar Ecol Prog Ser 457:151-162

Takahashi A, Matsumoto K, Hunt GL, Shultz MT and others (2008) Thick-billed murres use different diving behaviours in mixed and stratified waters. Deep-Sea Res II 55: 1837-1845

Thaxter CB, Daunt F, Hamer KC, Watanuki Y and others (2009) Sex-specific food provisioning in a monomorphic seabird, the common guillemot Uria aalge: nest defence, foraging efficiency or parental effort? J Avian Biol 40: 75-84

Votier SC, Bearhop S, Witt MJ, Inger R, Thompson D, New-

Editorial responsibility: Jacob González-Solís,

Barcelona, Spain ton J (2010) Individual responses of seabirds to commercial fisheries revealed using GPS tracking, stable isotopes and vessel monitoring systems. J Appl Ecol 47: 487-497

- Votier SC, Bicknell A, Cox SL, Scales KL, Patrick SC (2013) A bird's eye view of discard reforms: bird-borne cameras reveal seabird/fishery interactions. PloS ONE 8:e57376

Wakefield ED, Phillips RA, Matthiopoulos J (2009) Quantifying habitat use and preferences of pelagic seabirds using individual movement data: a review. Mar Ecol Prog Ser 391:165-182

- Wakefield ED, Phillips RA, Belcher M (2012) Foraging blackbrowed albatrosses target waters overlaying moraine banks - a consequence of upward benthic-pelagic coupling? Antarct Sci 24:269-280

> Wakefield ED, Bodey TW, Bearhop S, Blackburn J and others (2013) Space partitioning without territoriality in gannets. Science 341:68-70

Wakefield ED, Phillips RA, Matthiopoulos J (2014) Habitatmediated population limitation in a colonial central-place forager: The sky is not the limit for the black-browed albatross. Proc R Soc Lond B Biol Sci 281:20132883

> Wanless S, Harris MP, Greenstreet SPR (1998) Summer sandeel consumption by seabirds breeding in the Firth of Forth, south-east Scotland. ICES J Mar Sci 55:1141-1151

- Wearmouth VJ, Sims DW (2008) Sexual segregation in marine fish, reptiles, birds and mammals: behaviour patterns, mechanisms and conservation implications. Adv Mar Biol 54:107-170

> Weimerskirch H (1991) Sex-specific differences in molt strategy in relation to breeding in the wandering albatross. Condor 93:731-737

> Weimerskirch H, Le Corre M, Ropert-Coudert Y, Kato A, Marsac F (2006) Sex-specific foraging behaviour in a seabird with reversed sexual dimorphism: the red-footed booby. Oecologia 146:681-691

Weimerskirch H, Shaffer SA, Tremblay Y, Costa DP and others (2009) Species- and sex-specific differences in foraging behaviour and foraging zones in blue-footed and brown boobies in the Gulf of California. Mar Ecol Prog Ser 391:267-278

Wilson RP (2003) Penguins predict their performance. Mar Ecol Prog Ser 249:305-310

Wood SN (2006) Generalized additive models: an introduction with R. Chapman \& Hall, CRC Press, Boca Raton, FL

> Woodcock P, Edwards DP, Newton RJ, Ansell FA, Chey VK, Bottrell SH, Hamer KC (2012) Assessing trophic position from nitrogen isotope ratios: effective calibration against spatially varying baselines. Naturwissenschaften 99:275-283

Zavalaga CB, Benvenuti S, Dall'Antonia L, Emslie SD (2007) Diving behavior of blue-footed boobies Sula nebouxii in northern Peru in relation to sex, body size and prey type. Mar Ecol Prog Ser 336:291-303

Submitted: June 12, 2014; Accepted: November 8, 2014 Proofs received from author(s): December 15, 2014 